\title{
Cercospora habenariicola, a new record for India
}

\section{Patil A, Patil MS and Dangat BT ${ }^{1}$}

Department of Botany, Rajaram College, ${ }^{1}$ Shivaji University, Kolhapur, (M.S), India dhirajanj@gmail.com, ${ }^{1}$ schndangat@gmail.com

Patil A, Patil MS, Dangat BT 2012 - Cercospora habenariicola, a new record for India. Plant Pathology \& Quarantine 2(2), 112-115, doi 10.5943/ppq/2/2/3

Cercospora habenariicola is recorded for the first time from India on seven species of Orchidaceae: Habenaria roxburghii, $H$. heyneana, $H$. longicorniculata, $H$. ovalifolia, Pecteilis gigantea, Peristylus densus, and P. goodyeroides.

Keywords - Cercospora - Habenaria - Pecteilis - Peristylus

\section{Article Information}

Received 2 May 2012

Accepted 6 August 2012

Published online 5 September 2012

*Corresponding author: Dangat BT - e-mail - schndangat@gmail.com

\section{Introduction}

To date about 5500 species of Cercospora are known (Crous \& Braun, 2003). Nine species of Cercospora sensu lato have been recorded on hosts of family Orchidaceae, of which four species have been transferred to Pseudocercospora Speg. (Meeboon et al., 2007). Only one species of Cercospora has been reported on Orchidaceae from India, Cercospora eulophiae on Eulophia sp. (Patil,M.S., 1978).

The present paper records Cercospora habenariicola Meeboon, Hidayat \& C. Nakash. for the first time from India. Meeboon et al. (2007) described C. habenariicola from Thailand on Habenaria susannae (L.) R.Br. It was found on seven species of Orchidaceae in India: Habenaria heyneana, H. longicorniculata, $H$. ovalifolia, $H$. roxburghii, Pecteilis gigantea, Peristylus densus and P. goodyeroides.

\section{Materials and Methods}

Healthy and infected specimens were collected from Kolhapur, Gaganbawda, Radhanagari and Panhala (Dist. Kolhapur, M.S.), Kas, Mahabaleshwar (Dist. Satara, M.S.), Sutakatti Ghat (Dist. Belgaum, K.S.) and Uttur (Dist. Ajara, M.S.) India in the period July-September 2010-11. Detailed observations of morphological characters were carried out under light microscope by preparing hand-cut sections, which were mounted in lactophenol cotton blue. Measurements were made of infection spots, stromata, conidiophores and conidia. Drawings were made with the help of a Camera Lucida at a magnification of $400 \mathrm{x}$ (Fig. 1).Dried herbarium specimens have been deposited in National Fungal Culture Collection of India, Agahrkar Research Institute, Pune (NFCCI).

\section{Results} of;

Habitat - On living leaves and bracts

1. Habenaria heyneana Lindl., collected at Kolhapur, Radhanagari Gaganbawada, Panhala (Dist. Kolhapur, M.S.), Kas, Mahabaleshwar (Dist. Satara, M.S.), Uttur, (Ajara, Dist. Kolhapur, M.S.), NFCCIAMH no. 9411.

2. Habenaria longicorniculata J. Graham, collected at Kolhapur, Radhanagari Gaganbawada, Panhala (Dist. Kolhapur, M.S.), Kas, Mahabaleshwar (Dist. Satara, 

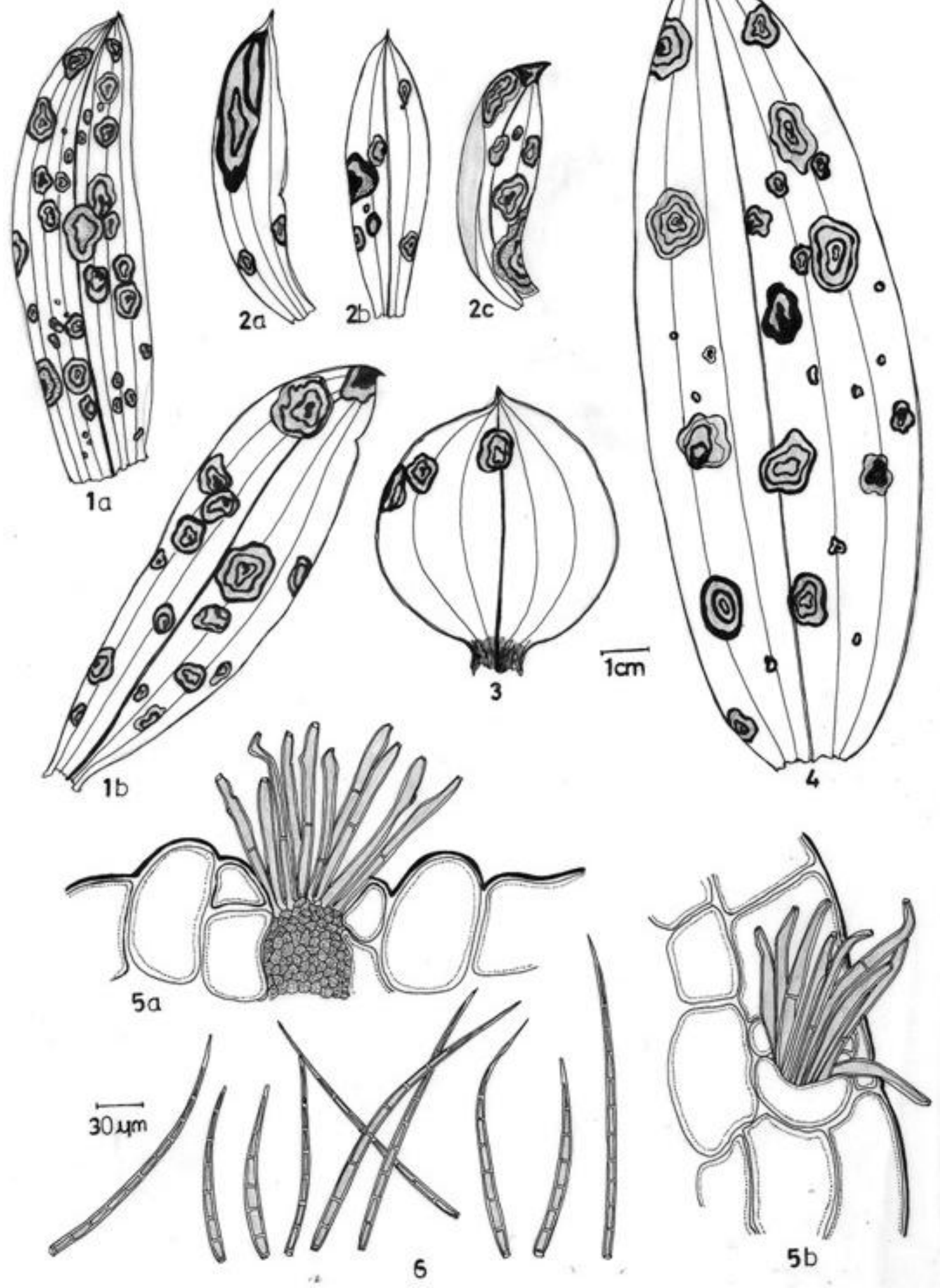

Figs 1-6 1a,b Habit, on leaf of $H$. longicorniculata $\times$ natural size. 2a-c Habit, on leaf of $H$. heyneana $\times$ natural size. 3 Habit, on leaf of $H$. roxburghii x natural size. 4 Habit, on leaf of Pecteilis gigantea $\times$ natural size. 5a,b Stromata and conidiophores; a intra-epidermal, b sub-stomatal, $400 \times$. 6 Conidia $400 \times$. 
Table 1 Comparative characters of Cercospora habenariicola on different hosts

\begin{tabular}{|c|c|c|c|c|c|}
\hline Species & Host & Infection & Stroma & $\begin{array}{c}\text { Conidiophores } \\
\mu \mathrm{m}\end{array}$ & Conidia $\mu \mathrm{m}$ \\
\hline $\begin{array}{l}\text { Cercospora habenariicola } \\
\text { (Meeboon et. al. 2007) }\end{array}$ & Habenaria susannae & amphigenous & Intra epidermal & Branched $7.3-7.5 \times 50-285(-952)$ & $4.9-5.0 \times 75-110$ \\
\hline Present collection & Habenaria roxburghii & hypophyllous & $\begin{array}{l}\text { Intra epidermal / } \\
\text { sub-stomatal }\end{array}$ & Branched 3-5 x 120-175 & $3.5-5 \times 90-150$ \\
\hline Present Collection & H. heyneana & hypophyllous & $\begin{array}{l}\text { Intra epidermal / } \\
\text { sub-stomatal }\end{array}$ & Branched $2.5-3 \times 120-165$ & $3-3.5 \times 35-55$ \\
\hline Present collection & H.longicorniculata & hypophyllous & $\begin{array}{l}\text { Intra epidermal / } \\
\text { sub-stomatal }\end{array}$ & Branched 3-5 x 122-180 & $3.5-5 \times 55-110$ \\
\hline Present collection & H. ovalifolia & hypophyllous & $\begin{array}{l}\text { Intra epidermal / } \\
\text { sub-stomatal }\end{array}$ & Branched 3-5 x 122-180 & $2-2.5 \times 65-125$ \\
\hline Present collection & Peristylus densus & hypophyllous & $\begin{array}{l}\text { Intra epidermal / } \\
\text { sub-stomatal }\end{array}$ & Branched 3-5 x 50-62.5 & $2-2.5 \times 65-123.5$ \\
\hline Present collection & Peristylus goodyeroides & hypophyllous & $\begin{array}{l}\text { Intra epidermal / } \\
\text { sub-stomatal }\end{array}$ & Branched 3-5 x 122-180 & $2-2.5 \times 65-125$ \\
\hline Present collection & Pecteilis gigantea & hypophyllous & $\begin{array}{l}\text { Intra epidermal / } \\
\text { sub-stomatal }\end{array}$ & Branched 3-5 x 62.5-75 & $2-2.5 \times 160.5-187.5$ \\
\hline
\end{tabular}


M.S.), Uttur, (Ajara, Dist. Kolhapur, M.S.) NFCCI- AMH no. 9412.

3. Habenaria ovalifolia Wight, collected at Gawse (Ajara, Dist. Kolhapur), Radhanagari and Patgaon (Dist. Kolhapur, M.S.) NFCCIAMH no. 9440.

4. Habenaria roxburghii Nicolson, collected at Kas, Mahabaleshwar and Sutakatti Ghat (Dist. Belgaum, K.S.) NFCCI- AMH no. 9410.

5. Pecteilis gigantea Raf., collected at Radhanagari and Gaganbawda. NFCCIAMH no. 9409.

6. Peristylus densus (Lindl.) Santapau \& Kapadia, collected at Radhanagari and Kas. NFCCI- AMH no. 9413.

7. Peristylus goodyeroides Lindl., collected at Gawse (Ajara, Dist. Kolhapur), Radhanagari and Patgaon, (Dist. Kolhapur, M.S.) NFCCI- AMH no. 9439.

All specimens were collected by $\mathrm{Dr}$ A.R. Patil and Mr B.T. Dangat in the months of August to September 2010-12.

All the specimens collected show similarities with Cercospora habenariicola (Table 1). The lesions in the present material are dark brown to black in colour, circular to irregular, up to $2 \mathrm{~mm}$ in diameter. Leaf spots are hypophyllous and not amphigenous as described for $C$. habenariicola (Meeboon et al. 2007). The stromata in the present materials are sub-stomatal and not intra-epidermal. The present collections show similarities to Cercospora habenariicola with regard to infection which is foliicolus, circular dark brown leaf spots, presence of stromata, conidiophores in spreading fascicles, collected on species of Habenaria. However, the present collections also differ in that the colonies are hypophyllous, the stromata are sub-stomatal, the conidiophores are simple, and the conidiophores and conidia are slightly smaller than reported for $C$. habenariicola (Meeboom et al. 2007). However, taking into consideration all characters, the present materials match well with $C$. habenariicola. The few variations may be due to ecological conditions. C. habenariicola is a new record to the fungi of India.

\section{References}

Crous PW, Braun U. 2003 - Mycosphaerella and its anamorphs: 1. Names published in Cercospora and Passalora. CBS Biodiversity Series 1.

Meeboon J, Iman Hidayat, Chiharu Nakashima, Caiwat To-Anun. 2007 - Cercospora habenariicola sp. nov. and some new records of cercosporoid fungi from Thailand. Mycotaxon 99, 117-121

Patil, M.S. 1978 - Some species of Cercospora from Maharashtra-VII. Indian Phytopathology 31, 327-330. 